\title{
MENINGKATKAN HASIL BELAJAR GERAK DASAR MELEMPAR DENGAN MEDIA AUDIO VISUAL PADA SISWA KELAS III SDN 03 JELAMBAR BARU JAKARTA BARAT
}

\author{
${ }^{1}$ Yusmawati, ${ }^{2}$ Taufik Rihatno, ${ }^{3}$ Rismawanti \\ ${ }^{1-3}$ Program Studi Pendidikan Jasmani, Fakultas Ilmu Olahraga Universitas Negeri Jakarta, Jl. Pemuda \\ No 10 Jakarta, Indonesia \\ Email: yusmawati@unj.ac.id
}

\begin{abstract}
Abstrak. Penelitian ini bertujuan untuk meningkatkan hasil belajar melempar dengan media audio visual. Subjek penelitian adalah siswa kelas III A SDN 03 Jelambar Baru Jakarta Barat yang terdiri dari 30 siswa. Metode yang digunakan yaitu metode Penelitian Action Research, yakni dengan memberi tindakan khusus kepada subjek untuk meningkatkan hasil belajar gerak dasar melempar melalui media audio visual. Hasil penelitian, yaitu melalui metode penelitian tindakan dengan menggunkan alat bantu belajar audio visual dapat meingkatkan hasil belajar gerak dasar melempar pada siswa kelas III SDN 03 Jelambar Baru Jakarta Barat, hal ini terlihat dari tingkat kelulusan subjek dari tes awal berjumlah 10 siswa atau presentase 33,3\% sedangkan 20 siswa atau presentase $66,7 \%$ belum mencapai nilai kelulusan. Setelah melakukan tindakan siklus kedua hasil kelulusan meningkat signifikan semua siswa sudah dapat melakukan tahapan gerak dasar melempar dengan benar, kelulusan pada tes terakir berjumlah 30 siswa atau presentase $100 \%$.
\end{abstract}

Kata Kunci : gerak dasar, melempar, audio visual

\section{PENDAHULUAN}

Pendidikan jasmani pada dasarnya merupakan bagian integral dari sistem pendidikan secara keseluruhan, bertujuan untuk mengembangkan aspek kesehatan, kebugaran jasmani, keterampilan berpikir kritis, stabilitas emosional, keterampilan sosial, penalaran dan tindakan moral melalui aktifitas jasmani dan olahraga.

Namun demikian tidak semua guru pendidikan jasmani menyadari hal tersebut, sehingga banyak anggapan bahwa pendidikan jasmani boleh dilaksanakan secara serampangan. Hal ini tercermin dari berbagai gambaran negatif tentang pembelajaran pendidikan jasmani, mulai dari kelemahan proses yang menetap misalnya membiarkan anak bermain sendiri hingga rendahnya mutu hasil pembelajarannya, seperti kebugaran jasmani yang rendah. dikalangan guru pendidikan jasmani ada anggapan bahwa pelajaran pendidikan jasmani dapat dilaksanakan seadanya, sehingga masih ada pelaksanaan cukup dengan cara menyuruh anak pergi ke lapangan, menyediakan bola sepak untuk laki-laki dan bola voli untuk perempuan. Guru tinggal mengawasi dipinggir lapangan. Anak yang berada di kelas awal SD adalah anak yang berada pada rentangan usia dini. Masa usia dini merupakan masa yang pendek tetapi merupakan masa yang sangat penting bagi kehidupan seseorang. Oleh karena itu pada masa ini seluruh potensi yang dimiliki anak perlu didorong sehingga akan berkembang secara optimal. 
Karakteristik perkembangan anak pada kelas satu, dua, dan tiga SD biasanya pertumbuhan fisiknya telah mencapai kematangan, mereka telah mampu mengontrol tubuh dan keseimbangannya. Dengan demikian perkembangan anak pada masa sekolah dasar (SD) kelas rendah haruslah dikembangkan secara secara optimal dengan mengandalkan kemampuan mereka dan membuat mereka merasa nyaman dan senang saat pembelajaran.

Dalam proses belajar mengajar kehadiran media pun mempunyai arti yang cukup penting. karena dalam kegiatan tersebut ketidakjelasan bahan yang disampaikan dapat dibantu dengan menghadirkan media sebagai perantara. Kerumitan bahan yang akan disampaikan kepada anak didik dapat disederhanakan dengan bantuan media. Media dapat mewakili apa yang kurang mampu guru ucapkan melalui kata-kata atau kalimat tertentu. Bahkan keabstrakan bahan dapat dikonkretkan dengan kehadiran media.

Sebagai alat bantu, media mempunyai fungsi melicinkan jalan menuju tercapainya tujuan pengajaran. hal ini dilandasi dengan keyakinan bahwa proses belajar mengajar dengan bantuan media mempertinggi kegiatan belajar anak didik dalam tenggang waktu yang cukup lama. Dengan itu berarti kegiatan belajar anak didik dengan bantuan media akan menghasilkan proses dan hasil belajar yang lebih baik daripada tanpa bantuan media. Telah banyak alat maupun media yang tersedia bagi guru, namun yang penting dalam merencanakan pembelajaran ialah bagaimana menggunkan alat-alat media pendidikan ini sebagai suatu sistem yang terintegrasi dalam pembelajaran. Tugas seorang pendidik adalah tugas profesional, selalu menghadapi tantangan apabila ingin menjadi pendidik yang kreatif, dinamis, kritis, dan ilmiah. sebelum ia menentukan bahan pelajaran, ia harus menentukan tujuan intruksional yang sesuai dengan tingkat kemampuan siswa, kemampuan apa yang akan dikembangkan, menyusun kegiatan belajar mengajar, untuk ini ia harus mampu menentukan media dan metode pengajaran yang tepat. Melempar adalah suatu gerakan yang menyalurkan tenaga pada suatu benda yang menghasilkan daya pada benda tersebut dengan memiliki kekuatan kedepan atau ke atas, (Yusmawati, disertasi 2012). Melempar juga salah satu gerakan yang mendasari aktifitas permainan atau olahraga itu dibentuk, serta gerak dasar melempar merupakan bagian dari materi yang berada didalam mata pelajaran pendidikan jamani disekolah dasar.

Namun pada kenyataannya dalam proses pembelajaran penjas khususnya pada materi melempar banyak guru yang tidak dapat memanfaatkan adanya media yang disedikan disekolah dan pada saat pembelajaran melempar, masih banyak siswa yang melakukan gerakan yang terlihat kurang tepat misalnya kaki dan tangan yang digerakan kedepan sama arahnya sehingga membuat siswa kurang atau tidak seimbang saat melakukan gerakan lemparan. Selain itu, kurangnya motifasi mereka untuk mengikuti pembelajaran dalam melakukan kegiatan melempar, sehingga muncul keluhan mengenai media pembelajaran yang kurang menarik dan termasuk dalam tingkat kesulitan bagi siswa maupun siswi SDN 03 Jelambar Baru Jakarta Barat hingga kini belum terpecahkan.

Berdasarkan hasil pengamatan yang dilakukan di SDN 03 Jelambar Baru Jakarta Barat, Penulis melihat bahwa 
kemampuan penguasaan gerak dasar melempar siswa tersebut masih perlu di perbaiki dan ditingkatkan. Hal ini dapat dilihat pada saat para siswa melakukan gerak dasar melempar yang masih kurang tepat, di duga karena kurangnya media pembelajaran yang dapat diterima oleh para siswa. dan pembelajaran yang membosankan. Dalam hal ini, penulis ingin mecoba meningktkan hasil belajar dengan media dengan audio visual guna dapat memberikan dampak yang positif agar siswa mampu dan memahami gerak dasar melempar dengan baik dan benar.

Dengan Menggunakan Media audio visual juga diharapkan siswa dapat memahami dan dapat mempraktekan gerak dasar melempar dengan pergerakan tangan dan kaki serta posisi tubuh yang baik dan benar serta siswa dapat belajar dengan suasana belajar yang berbeda dan tidak membosankan. Dengan demikian setelah semua unsur yang telah dikemukakan tersebut maka penulis tertarik untuk mencoba penelitian yang berfokus pada "Meningkatkan hasil belajar gerak dasar melempar dengan audio visual pada siswa kelas III SDN 03 Jelambar Baru Jakarta Barat".

Penelitian ini mengenai pembelajaran gerak dasar melempar dengan audio visual yang dapat di identifikasi dalam pertanyaan yaitu : "Apakah pembelajaran gerak dasar melempar dengan media audio visual dapat meningkatkan hasil belajar siswa pada siswa kelas III SDN Jelambar Baru Jakarta Barat ?"

\section{KONSEP PENELITIAN TINDAKAN}

Metode Penelitian Tindakan (Action Research) sebagai salah satu model penelitian yang muncul di tempat kerja, tempat dimna peneliti melakukan pekerjaan sehar-hari.

Dengan kata lain menurut Kemmis dan MC Taggart, Penelitian Tindakan (Action Research) adalah cara suatu kelompok atau seseorang dalam mengorganisasi suatu kondisi sehingga mereka dapat mempelajari pengalaman mereka dan membuat pengalaman mereka diakses oleh orang lain. Dalam kenyataannya, penelitian tindakan dapat dilakukan baik secara grup maupun individual dengan harapan pengalaman mereka dapat ditiru atau diakses untuk memperbaiki kualitas kerja orang lain. Secara praktis, penelitian tindakan pada umumnya sangat cocok untuk meningkatkan kualitas subjek yang hendak diteliti. Subjek penelitian tindakan ini dapat berupa kelas yang berusaha meningkatkan kualitas.

Menurut penjelasan tersebut metode penelitian tindakan adalah cara seseorang atau suatu kelompok dalam mengorganisasikan suatu kondisi sehingga mereka dapat mempelajari penglaman mereka dan pengalamana mereka dapat diakses oleh orang lain dengan harapan pengalaman mereka dapat ditiru atau diakses untuk memperbaiki kualitas kerja orang lain. Metode Peneitian tindakan ini sangat cocok untuk meningkatkan suatu objek yang hendak diteliti Subjek penelitian tindakan ini dapat berupa kelas maupun sekelompok orang yang bekerja di industri atau lembaga sosial lain yanga berusaha meningkatkan kualitas kinerja.

\section{KONSEP MODEL TINDAKAN}

Model penelitian tindakan ini dikembangkan oleh Stephen Kemmis dan Robin Mc Taggart pada tahun 1988. 
Model penelitian ini menggunakan empat komponen penelitian tindakan (Perencanaan, tindakan, observasi, dab refleksi) dalam suatu sistem spiral yang saling terkait

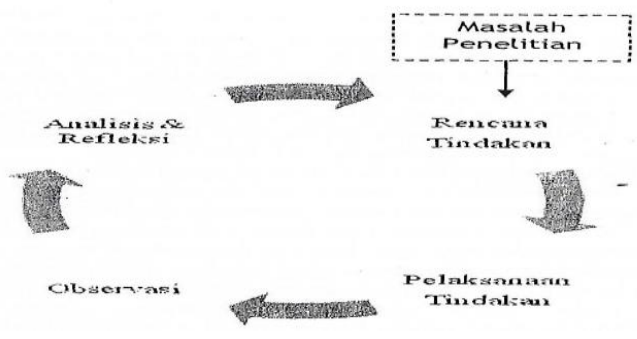

Tujuan belajar sangat penting dalam proses pembelajaran baik bagi guru maupun bagi siswa. Dalam proses tersebut siswa mengalami proses pembelajaran dan merespon dengan prilaku belajar. pada umumnya siswa belum menyadari pentingnya belajar.

Belajar merupakan kegiatan yang wajib dilakukan oleh setiap siswa disekolah, baik di dalam kelas maaupun di luar kelas. belajar dapat di lakukan di dalam maupun di luar ruangan dan belajar bisa dilakukan dengan siapa saja dan kapan saja, karna segala pengalaman dan pengetahuan baru adalah salah satu dari proses belajar.

Perubahan Tingkah laku yang berlangsung secara sadar dan melibatkan segenap aktifitas siswa adalah merupakan proses belajar mengajar dapat dikatakan berhasil apabila, siswa telah memahami proses belajar mengajar serta mampu mencapai tujuan yang telah ditetapkan. Maka hasil dari perubahan tingkah laku dari proses belajar mengajar inilah yang disebut dengan Hasil Belajar.

Pengertian belajar gerak tidak terlepas dari pengertian belajar pada umumnya. Belajar gerak merupakan sebagian dari belajar. Belajar yang menekankan pada aktivitas berfikir bisa disebut belajar kognitif. Belajar yang menekankan pada aktivitas emosi dan perasaan bisa disebut belajar afektif. Sedangkan belajar yang menekankan pada aktivitas gerak tubuh disebut belajar gerak. Setiap macam belajar mempunyai keunikannya masing-masing. kunikannya bisa dilihat dalam hal-hal materi yang dipelajari, proses belajarnya, kondisi belajarnya, intensitas keterlibatan setiap unsur domain kemampuannya, serta hasil belajarnya.

Menurut Jhon N. Drowtzky definisi yang dibuatnya yaitu: "Belajar gerak adalah belajar yang diwujudkan melalui respon-respon muskular yang diekspresikan dalam gerakan tubuh atau bagian tubuh". Proses belajar gerak ada tiga fase, yaitu fase kognitif, asosiatif, dan otonom ketiga fase terseut adalah proses belajar gerak siswa dari memulai untuk mencoba pembelajaran sampai dengan kemahiran yang dapat dilakukan secara otmatis.

Didalam ranah gerak ada tiga kelompok gerak fundamental yaitu :
a. Gerak Lokomotor
b. Gerak non lokomototr
c. Gerak Manipulatif

Dalam hal ini, bentuk kemampuan manipulatif salah satunya adalah kemampuan gerak dasar melempar.

\begin{tabular}{llr}
\multicolumn{2}{c}{ Kemampuan } & \multicolumn{2}{c}{ Manipulatif } \\
dikembangkan ketika anak & telah \\
menguasi macam-macam & objek.
\end{tabular} Kemampuan manipulatif lebih banyak melibatkan, tetapi bagian lain dari tubuh kita juga dapat digunakan. Manipulasi objek jauh lebih unggul dari pada kordinasi mata-kaki dan tangan-mata, yang mana cukup penting untuk item berjalan (gerakan langkah) dalam ruang. Bentuk-bentuk kemampuan manipulatif terdiri dari: Gerakan Mendorong 
(melempar, memukul, menendang). Gerakan menerima (Menangkap). Gerakan memantul-mantulkan bola atau menggiring bola.

Melempar adalah salah satu gerakan yang menyalurkan tenaga pada suatu benda yang menghasilkan daya pada bentuk tersebut dengan memiliki kekuatan kedepan atau keatas. Melempar mempunyai beberapa gerak dasar dengan tangan kiri atau kanan.

Keterampilan melempar kedepan di atas lengan (overarm throwing) adalah keterampilan yang paling umum digunakan dalam olahraga untuk melempar jauh dan untuk membuat umpan cepat yang akurat. Variasi lemparan kedepan biasa digunakan dalam banyak acara di lapangan atletik, dalam kegiatan melempar dan menangkap, dan dalam permainan bola kecil maupun bola besar misalnya kasti, softball dan sebagainya. Sebagian besar anak-anak tidak akan secara naluriah tahu bagaimana melempar kedepan secara efisien, untuk mencapai tahap matang keterampilan mereka membutuhkan berbagai kesempatan latihan yang menyenangkan dan menarik.

Menurut rangkaian melempar dalam buku teo koh sok miang dapat dilihat pada gambar berikut :

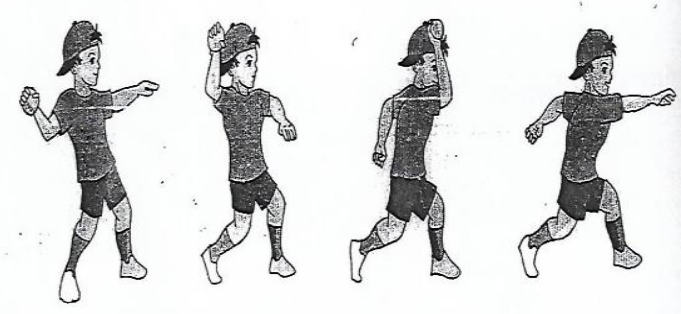

Jadi pengertian melempar dapat disimpulkan bahwa gerak dasar melempar adalah salah satu gerakan yang menyalurkan tenaga pada suatu benda yang menghasilkan daya pada bentuk tersebut dengan memiliki kekuatan kedepan atau keatas dan melempar merupakan salah satu gerak manipulatif untuk menjauhkan objek dari tubuh. Dan keterampilan melempar sering dan sudah umum digunkan untuk beberapa cabang olahraga. Gerak dasar melempar yang baik dan bernar berpengaruh kepada hasil dalam melemper oleh karna itu harus melakukan gerak dasar melempar secara baik dan benar. Adapun rangkaian yang harus dilakukan dengan baik dan benar, Yaitu (1) Pandangan, (2) Lengan Tangan, (3) Badan, dan (4) Tungkai kaki.

Kata media berasal dari bahasa Latin medius yang secara harfiah berarti 'tengah', 'perantara' atau 'pengantar' dalam bahasa Arab media adalah pentara atau pengantar pesan dari pengirim kepada peneima pesan. Menurut Gerlach \& Ely yang dikutip oleh Azar Arsyad mengatakan bahwa media apabila dipahami secra garis besar adalah manusia, materi, atau kejadin yang membangun kondisi yang membuat siswa mampu memperoleh pengetahuan, keterampilan, atau sikap. Dalam pengertian ini berarti, guru, buku teks, dan lingkungan sekolah merupakan media. Media yang mampu membantu dalam proses belajar mengajar. Di samping sebagai sistem penyampai atau pengantar, media yang sering diganti dengan kata mediator.

Dari pandangan tersebut dapa dikatakan bahwa mediamerupakan alat yang memungkinkan anak muda untuk megerti dan memahami sesuatu dengan mudah dan dapat mengingatnya dalam waktu yang lama dibandingkan dengan penyampaian materi pembelajaran dengan 
cara tatap muka dan ceramah tanpa alat bantuan.

Menurut Wingkle media audio visual adalah kombinasi antara audio dan visual yang diciptakan sendiri seperti slide yang dikombinasikan dengan kaset audio. Dan menurut Wina Sanjaya media audio visual adalah media yang mempunyai unsur suara dan unsur gambar yang bisa dilihat, misalnya rekaman video, slide, suara, dan sebagainya. Dari beberapa pendapat di atas dapat disimpulkan bahwa media audio visual adalah media kombinasi antara audio dan visual yang dikombinasikan dengan kaset audio dan visual yang mempunyai unsur suara dan gambar yang bisa dilihat misalnyarekaman video, slide suara dan sebagainya. Belajar dengan menggunkan indra ganda pandang dan dengar berdasarkan konsep diatas akan memberikan keuntungan bagi siswa. siswa akan belajar lebih banyak dari pada jika materi pelajaran disajikan hanya dengan stimulus pandang atau hanya dengan stimulus dengar. Akhirnya dapat dipahami bahwa media adalah alat bantu dalam proses belajar mengajar. Dan gurulah yang mempergunakannya untuk pembelajaran anak didik demi tercapainya tujuan pengajaran.

Salah satu media yang digunakan dalam pembelajaran dan diyakini dapat lebih menggairahkan animo siswa dalam pembelajaran adalah audio visual.

Media Audio visual juga merupakan salah satu sarana dalam melakukan proses pembelajaran berbasis teknologi. Audio pembelajaran berbasis teknologi ini dapat digunakan sebagai sarana alternatif mengoptimalkan proses pembelajaran, dikarenakan beberapa aspek antara lain: a) mudah dikemas dalam proses pembelajaran, b) Lebih menarik untuk pembelajaran, dan c) Dapat diedit (diperbaiki) setiap saat. dengan memanfaatkan teknologi komputer diharapkan bahwa audio visual pembelajaran dapat digunakan untuk menyampaikan materi pembelajaran yang lebih menarik, termasuk visualisasi materi bahan ajar. Sehingga lebih menarik dikalangan siswa melalui audio visual pembelajaran dapat lebih interaktif dan lebih memungkinkan terjadinya two way trafic dalam proses pembelajaran.

Media Audio visual adalah media yang mempunyai unsur suara dan unsur gambar. sejenis media ini mempunyai kemampuan yang lebih baik, karna meliputi kedua jenis media yang pertama dan kedua. Media ini di bagi lagi ke dalam: Audio visual Diam, yaitu media yang menampilkan suara dan gambar diam seperti film bingkai suara (sound slides), film rangkai suara, dan cetak suara .Audio visual Gerak, yaitu media yang dapat menampilkan unsur suara dan gambar yang bergerak seperti film suara dan video cassette.

Pembagian lain dari media ini adalah : Audio visual murni, yatu baik unsur suara maupun unsur gambar berasal dari satu sumber seperti film videocassette.

Audio visual tidak murni, yaitu yang unsur suara dan unsur gambarnya berasal dari sumber yang berbeda, misalnya film bingkai suara yang unsur gambarnya berasal dari slides proyektor dan unsur suaranya berasal dari tape recorder. contoh lainnya adalah film strip suara dan cetak suara.

Anak kelas III SD berada pada Fase anak besar yaitu umur $6-10$ tahun untuk anak perempuan dan $6-12$ tahun untuk anak laki-laki. Pada umumnya anak SD 
terutama kelas-kelas rendah itu senang bermain. Karakteristik ini menuntut guru SD untuk melaksanakan kegiatan pendidikan yang bermuatan permainan lebih-lebih untuk kelas rendah. Karakteristik perkembangan anak kelas satu, dua, dan tiga SD biasanya pertumbuhan fisiknya telah mencapai kematangan, mereka telah mampu mengontrol tubuh dan keseimbangannya. Mereka telah dapat melompat dengan kaki secara bergantian, dapat mengendarai sepedah roda dua, dapat menangkap bola dan telah berkembang koordinasi tangan dan mata untuk dapat memegang pensil maupun memegang gunting. Selain itu, perkembangan sosial anak yang berada pada usia kelas awal SD anatara lain mereka telah dapat menunjukan keakuannya tentang jenis kelaminnya, telah mulai berkompetisi dengan teman sebaya, mempunyai sahabat, telah mampu berbagi, dan mandiri. Anak usia sekolah dasar berada pada tahapan oprasi konkret. pada rentan usia tersebut anak mulai menunjukan prilaku belajar sebagai berikut : (1) mulai memandang dunia dengan objektif, bergeser dari satu aspek ke aspek lain secara reflektif dan memandang unsurunsur secara serentak, (2) mulai berpikir secara operasional, (3) menggunakan caraberpikir operasional untuk mengklasifikasikan benda-benda, (4) membentuk dan menggunakan keterhubungan aturan-aturan perinsip ilmiah sederhana, dan menggunkan hubungan sebab akibat, dan (5) memahami konsep substansi, volume zat cair, panjang, lebar, luas dan berat. Siswa kelas tiga Sekolah Dasar berada dalam tahap konkret, dengan demikian dalam memberikan materi pembelajaran guru diharapkan lebih menitik beratkan pada alat peraga atau media yang bersifat konkret dan logis. Dengan memperhatikan karakteristik kognitif siswa kelas tiga Sekolah Dasar dengan segala aspek dimensi perkembangannya, maka diharapkan sistem pengajaran yang dikembangkan mampu melayani kebutuhan belajar yang bermakna bagi bagi siswa. Perkembangan fisik yang normal merupakan salah satu faktor penentu kelancaran proses belajar, baik dalam bidang pengetahuan maupun keterampilan. oleh karena itu, perkembangan motorik sangat menunjang keberhasilan belajar peserta didik. Pada masa usia sekolah dasar kematangan perkembangan motorik ini pada umumnya dicapainya, karena itu mereka sudah siap menerima pelajaran keterampilan.

\section{HASIL DAN PEMBAHASAN}

Deskripsi Hasil Tes Awal

Pada tanggal 17 Juli 2018 peneliti melakukan pelaksanaan kegiatan observasi awal dan tes awal pada kelas III SDN 03 Jelambar Baru Jakarta Barat untuk mengetahui kondisi awal terhadap pembelajaran pendidikan jasmani khususnya untuk pembelajaran gerak dasar melempar, adapun hasil tes awal sebagai berikut:

Nilai terendah 51 , nilai tertinggi 85 , dan nilai rata-rata 70 .

\section{Tabel 4.1. Distribusi Frekuensi Nilai Pada Tes Awal}

\begin{tabular}{c|c|c|c|c} 
No & $\begin{array}{c}\text { Interval } \\
\text { Kelas }\end{array}$ & $\begin{array}{c}\text { Nilai } \\
\text { Tengah } \\
(\mathrm{xi})\end{array}$ & $\begin{array}{c}\text { Frekuensi } \\
(\mathrm{f})\end{array}$ & $\begin{array}{c}\text { Presentase } \\
(\%)\end{array}$ \\
\hline 1 & $51-56$ & 53,5 & 3 & $10 \%$ \\
\hline 2 & $57-62$ & 59,5 & 5 & $16,7 \%$ \\
\hline 3 & $63-68$ & 65,5 & 2 & $6,6 \%$ \\
\hline 4 & $69-74$ & 71,5 & 10 & $33,3 \%$
\end{tabular}




\begin{tabular}{c|c|c|c|c}
5 & $73-80$ & 77,5 & 5 & $16,7 \%$ \\
\hline 6 & $81-86$ & 83,5 & 5 & $16,7 \%$ \\
\hline & Jumlah & & 30 & $100 \%$
\end{tabular}

Sumber: Hasil Pengolahan Data

Adapun hasil penilaian tersebut dapat terlihat dalam histogram hasil tes awal sebagai berikut :

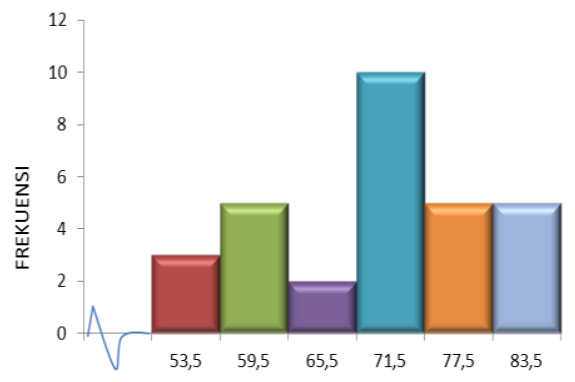

Gambar 4.1 Histogram Tes Awal

Pada pengambilan nilai t-tes awal ini, maka dapat terlihat kemampuan peserta didik yang masih memiliki kemampuan gerak dasar melempar sangat rendah sehingga banyak yang nilainya tidak lulus. pencapaian nilai siswa yang lulus dan tidak lulus dapat dilihat dari tabel berikut.

\section{Tabel 4.2. Distribusi Frekuensi} Kelulusan Pada Tes Awal

\begin{tabular}{c|c|c|c|c} 
No & Nilai & Kriteria & $\mathrm{F}$ & $\mathrm{F} \%$ \\
\hline 1 & $>75$ & Lulus & 10 & $33,3 \%$ \\
\hline 2 & $<75$ & $\begin{array}{l}\text { Tidak } \\
\text { Lulus }\end{array}$ & 20 & $66,7 \%$ \\
\hline & & Jumlah & 30 & $100 \%$
\end{tabular}

Sumber: Hasil Pengolahan Data

\section{Deskripsi Hasil Tes Akhir}

Kegiatan ini merupakan langkah pengamatan yang dilakukan setelah proses pembelajaran pada waktu siklus yang terdiri dari satu siklus melalui media berbasis audio visual pembelajaran gerak dasar melempar. maka hasil yang diperoleh peserta didik, sebagai berikut :

\section{Tabel 4.3. Distribusi Frekuensi Nilai Pada Tes Akhir}

\begin{tabular}{c|c|c|c|c} 
No & $\begin{array}{c}\text { Interval } \\
\text { Kelas }\end{array}$ & $\begin{array}{c}\text { Nilai } \\
\text { Tengah } \\
(\mathrm{xi})\end{array}$ & $\begin{array}{c}\text { Frekuensi } \\
(\mathrm{f})\end{array}$ & $\begin{array}{c}\text { Presentase } \\
(\%)\end{array}$ \\
\hline 1 & $77-80$ & 78,5 & 8 & $26,7 \%$ \\
\hline 2 & $81-84$ & 82,5 & 7 & $23,3 \%$ \\
\hline 3 & $85-88$ & 86,5 & 9 & $30 \%$ \\
\hline 4 & $89-92$ & 90,5 & 4 & $13,3 \%$ \\
\hline 5 & $93-96$ & 94,5 & 2 & $6,7 \%$ \\
\hline & Jumlah & & 30 & $100 \%$
\end{tabular}

Sumber: Hasil Pengolahan Data

Berdasarkan tabel di atas disimpulkan bahwa frekuensi terbesar terdapat pada interval kelas $85-88$ dengan nilai tengah 86,5 dan frekuensi 9 atau presentase $30 \%$. Maka dengan intervasl kelas pertama berada pada angka yang sama dengan nilai KKM, sehingga hasil menunjukan bahwa siswa telah lulus $100 \%$. Adapun penjelasan hasilnya dapat dilihat dengan histogram berikut :

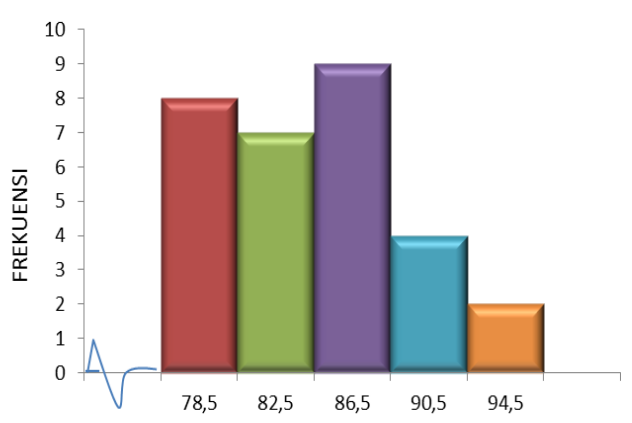

Gambar 4.2 Histogram Tes Akhir 
Berdasarkan histogram diatas menunjukan bahwa pelaksanaan pada penilaian tes akhir gerak dasar melempar pada siklus 1 setelah pertemuan kedua, terdapat peningkatan yang sangat signifikan sehingga semua siswa dapat melampaui standar nilai sesuai dengan KKM. Pencapaian nilai siswa yang lulus dan tidak lulus dapat dilihat, sebagai berikut :

\section{Tabel 4.4. Distribusi Frekuensi Kelulusan Pada Tes Akhir}

\begin{tabular}{c|c|c|c|c} 
No & Nilai & Kriteria & $\mathrm{F}$ & $\mathrm{F} \%$ \\
\hline 1 & $>75$ & Lulus & 30 & $100 \%$ \\
\hline 2 & $<75$ & $\begin{array}{c}\text { Tidak } \\
\text { Lulus }\end{array}$ & 0 & $0 \%$ \\
\hline & & Jumlah & 30 & $100 \%$
\end{tabular}

Sumber: Hasil Pengolahan Data

Pada tabel diatas dapat dilihat bahwa semua siswa memperoleh kemajuan yang terdapat pada nilali kelulusan siswa dalam melaksanakan tes akhir gerak dasar melempar setelah melakukan pembelajaran pada pertemuan pertama dan kedua. Sehingga dari 30 siswa yang lulus > 75 sebanak 30 siswa atau presentase $100 \%$.

\section{KESIMPULAN}

Berdasarkan penelitian yang telah dilakukan di SDN Jelambar Baru 03 pagi Jakarta Barat kelas IIIA, maka dapat disimpulkan bahwa belajar dengan audio visual dapat meingkatkan hasil belajar gerak dasar melempar pada siswa kelas III SDN Jelambar Baru 03 Pagi.

\section{DAFTAR PUSTAKA}

Ahmadi, Iif Khoiru dan Sofan Amri, (2010). Strategi Pembelajaran
Sekolah Berstandar Internasional \& Nasional, Jakarta: PT. Prestasi Putrakarya.

Arsyad, Azhar, (2010). Media Pembelajaran, Jakarta: PT RajaGrafindo Persada.

Djamarah ,Syaiful Bahri, (2006). Strategi Belajar Mengajar, Jakarta: PT Rineka Cipta.

Galahue, David L. \& John C. Ozmun, (1998). Understanding Motor Development Infants, Children, Adolescents, Adults, Singapura: McGraw-Hill Book Co.

Ma'mun, Anung, (1999). Perkembangan Gerak dan Belajar Gerak, Jakarta: dekdipbud Dirjendikdasmen.

Maksum, Ali, (2012). Metodelogi Penelitian dalam Olahraga, Surabaya: Unesa.

Miang, Teo-Koh Shock, Fundamental Movement Skills for Growing Active Learners, Singapore: The Singapore Sport Council.

Nazir, Moh, (2011). Metode Penelitian, Bogor: Ghalia Indonesia.

Paruwayan, Sekar Purbawini, (2018). Karakteristik Siswa SD Kelas Rendah dan Pembelajarannya, Yogyakarta: UNY.

Rihatno, Taufik \& Djumidar, (2015). Teori Dan Praktek Permainan Softball, Jakarta: Universitas Negeri Jakarta.

Rosdiani, Dini, (2012). Model Pembelajaran Langsung dalam Pendidikan Jasmani dan Kesehatan, Bandung:Alfabeta.

Samsudin, (2008). Pembelajaran Pendidikan Jasmani Olahraga dan Kesehatan SD/MI, Jakarta: Litera.

Saputra, Yudha M, (2001). Pembelajaran Atletik Di Sekolah Dasar, Jakarta: 
Direktorat Jenderal Olahraga Depdiknas.

Sudjana, Nana, (1989). Cara Belajar Siswa Aktif Dalam Proses Belajar Mengajar. Bandung: Sinar Baru.

Sudjana, Nana, (1989). Dasar - Dasar Proses Belajar Mengajar, Bandung: Sinar Baru.

Sugiyanto, (1993). Belajar Gerak, Jakarta.

Sugianto, (1993). Pertumbuhan dan Perkembangan Gerak, KONI Pusat: Jakarta.

Sugiyanto \& Sudjarwo, (1992). Materi Pokok Dan Perkembangan Belajar Gerak, Jakarta: Universitas Terbuka,.

Sukardi, (2003). Metode Penelitian Pendidikan Kopetensi dan Praktiknya, Jakarta: PT Bumi Aksara.

Yusuf, Syamsu, (2012). Psikologi Perkembangan Anak \& Remaja, Bandung: PT Remaja Rosdakarya.

http://www.frewaremini.com/2014/09/3tiga-gerak-dasar-jasmani.html (di akses pada tanggal 26 Maret 2018) 